\title{
Infrastructure and City Competitiveness in India
}

\author{
Somik V. Lall*, Hyoung Gun Wang*, \\ and Uwe Deichmann*
}

March 2010

\begin{abstract}
Do local improvements in infrastructure provision improve city competitiveness? What public finance mechanisms stimulate local infrastructure supply? And how do local efforts compare with national decisions of placing inter-regional trunk infrastructure? In this paper, we examine how the combination of local and national infrastructure supply improve city competitiveness, measured as the city's share of national private investment. For the empirical analysis, we collect city-level data for India, and link private investment decisions to infrastructure provision. We find that a city's proximity to international ports and highways connecting large domestic markets has the largest effect on its attractiveness for private investment. In comparison, the supply of local infrastructure services - such as municipal roads, street lighting, water supply, and drainage - enhance competitiveness, but their impacts are much smaller. Thus, while local efforts are important for competitiveness, they are less likely to be successful in cities distant from the country's main trunk infrastructure. In terms of financing local infrastructure, we find that a city's ability to raise its own source revenues by means of local taxes and user fees increases infrastructure supply, whereas as inter governmental transfers do not have statistically significant effects.
\end{abstract}

Keywords: urbanization, cities, India, infrastructure

JEL classification: O18, N95, R51

Copyright (C) UNU-WIDER 2010

*World Bank, e-mail of corresponding author: Slall1@worldbank.org

This study has been prepared within the UNU-WIDER project on Beyond the Tipping Point: Development in an Urban World directed by Jo Beall, Basudeb Guha-Khasnobis, and Ravi Kanbur.

UNU-WIDER gratefully acknowledges the financial contributions to the research programme by the governments of Denmark (Royal Ministry of Foreign Affairs), Finland (Ministry for Foreign Affairs), Sweden (Swedish International Development Cooperation Agency-Sida) and the United Kingdom (Department for International Development). 
The World Institute for Development Economics Research (WIDER) was established by the United Nations University (UNU) as its first research and training centre and started work in Helsinki, Finland in 1985. The Institute undertakes applied research and policy analysis on structural changes affecting the developing and transitional economies, provides a forum for the advocacy of policies leading to robust, equitable and environmentally sustainable growth, and promotes capacity strengthening and training in the field of economic and social policy making. Work is carried out by staff researchers and visiting scholars in Helsinki and through networks of collaborating scholars and institutions around the world.

www.wider.unu.edu

publications@wider.unu.edu

UNU World Institute for Development Economics Research (UNU-WIDER)

Katajanokanlaituri 6 B, 00160 Helsinki, Finland

Typescript prepared by Anne Ruohonen at UNU-WIDER

The views expressed in this publication are those of the author(s). Publication does not imply endorsement by the Institute or the United Nations University, nor by the programme/project sponsors, of any of the views expressed. 


\section{Introduction}

Following independence, India's metropolitan areas faced considerable disadvantages in attracting and developing industry. The country's industrial policy was used to pursue national policy goals of promoting spatially balanced development. Strict industrial licensing directed investment into lagging areas, and kept heavy industry out of metropolitan centres. The state was also actively engaged in large-scale industrial production and in development of industrial estates. These policies restricted the emergence of industrial clusters in competitive locations, and stifled the competitiveness of cities across the urban system. Starting in 1991, when structural reforms associated with the liberalization of the economy were put in place, the government relaxed regulations for locating industry in metropolitan areas, and reduced its own role in industrial production (Bajpai and Sachs 1999; Ahluwalia 2002).

As a consequence, new investments by the private sector now seek the most profitable locations. These include cities that offer good access to intermediate inputs and to domestic and international markets, provide reliable and high quality public services, and have a business environment conducive to entrepreneurship. Part of a city's attractiveness stems from natural geography and endowments beyond their control. Furthermore, in countries such as India, local decisionmakers can only indirectly influence national investment decisions that determine placement of interregional infrastructure such as major highways and transport hubs. That leaves local public goods and services which are within the direct control of city-level decisionmakers. These services will be important considerations for private investment decisions and their quality will largely depend on a city's ability to sustainably raise and allocate local revenues.

In this paper, we examine the relative contribution of local as opposed to national infrastructure endowments in determining the competitiveness of Indian cities since economic liberalization, with competitiveness being measured as an individual city's share of national private industrial investment. These investment decisions are determined by profits that entrepreneurs can expect to achieve by investing in specific cities. Profits are likely to depend on prices for physical inputs and local wage rates, as well as the quality of the city's infrastructure. For the empirical analysis, we undertake direct examination of infrastructure's contribution to the competitiveness of Indian cities. We extend the framework developed in Röller and Waverman (2001) for the telecommunications sector, and develop a model of infrastructure and industrial investment decisions at the city level, where local infrastructure is endogenously determined.

We also address the important issue of endogeneity in the assessment of interregional transport infrastructure. National infrastructure investment decisions are not made randomly but, rather, are made to connect cities that are already growing more rapidly than others, or to favour politically important cities such as state capitals. India's national highway development programme, including its multi-billion dollar golden quadrilateral, will not develop new roads. Instead, it will upgrade the quality of roads already connecting large and nationally important cities. Thus, interregional transport investments are correlated with observable and unobservable city-level characteristics, and not correcting for omitted variable bias will provide misleading estimates for transport infrastructure. 
This paper also asks another important policy question: Given that public infrastructure investment has significant impacts on firm investment decisions and, therefore, local development, how can local governments increase investments in public infrastructure under their jurisdiction? Specifically, which is the more effective scheme to finance public infrastructure investment: more transfers from national or state governments, or own revenue generation through municipal taxes? We examine the relative effectiveness of these two public financing schemes.

Our empirical application of this model draws on a unique dataset on industrial investment and city public finance for Indian cities in the 1990s. The data allow us to estimate spatially detailed models of city-level demand, supply, and investment impacts regarding improving infrastructure and public services. By building a city's investment profile over time, it becomes possible to assess how investment decisions respond to changes in local actions in terms of providing the public goods valued by firms.

Our main findings are that proximity to interregional infrastructure, measured by domestic market access and travel times to seaports, has large and significant effects on improving a city's attractiveness for private investment. Our indicator of market access is based on the New Economic Geography literature, and improves on commonly used indicators such as road length or road density as they are fraught with measurement error and do not account for network connectivity. We also find that the supply of local infrastructure services has a positive and significant effect on city-level investment attractiveness. Our measures of local infrastructure include municipal roads, street lighting, water supply and drainage. These effects are robust across econometric specifications and estimation procedures. However, the effects of domestic market access and proximity to ports are considerably larger than the effects of local infrastructure supply, indicating that a large part of city success is influenced by national programme placement decisions. Local efforts are important - but are not the main drivers of a city's economic success.

Further, a city's own efforts in revenue generation have significant effects on the supply of local infrastructure, while the supply effects through inter-governmental transfers are ambiguous. These results suggest that, while local decisionmakers have limited scope in overcoming disadvantages due to geography and national targeting of interregional transport investments, good fiscal policies can improve the delivery of local infrastructure services such as water supply and sanitation. These services translate into better quality of life for residents, but may change a city's economic fortunes.

The rest of the paper is organized as follows. In the next section, we outline the modelling framework and discuss how the integrated model of supply, demand, and growth extends existing analytic work in this field. This is followed by a brief description of the data, and we then report our main findings and offer our conclusions.

\section{A model of infrastructure supply, demand, and competitiveness}

Research on links between infrastructure and economic performance dates back to Hirschman's (1958) theories of unbalanced growth, and to contributions regarding the role of 'economic and social overhead capital' in national and regional development (Nurkse 1953; Nadiri 1970). Much of the empirical work over the past 20 years is based 
on econometric studies, where infrastructure enters as an input in aggregate production or cost functions. The basic premise behind these studies is that infrastructure is an intermediate public good that plays an active part in the production process. Thus, increasing the stock of infrastructure - as with increasing any other stock of capital will improve the productivity of existing firms and attract new firms into the region. Some of the most cited aggregate production function studies include Aschauer (1989) and Munnell (1990). Both papers estimate national time series regressions for the USA, and find output elasticities of infrastructure ranging from 0.3-0.4. This work gave rise to a number of infrastructure and growth studies in the 1990s that utilized various versions of cost and production functions to evaluate the contribution of public infrastructure at various spatial scales (nation, states, city) on output, incomes, and private capital formation (Holtz-Eakin and Schwartz 1995; Moomaw et al. 1995; Garcia-Mila and McGuire 1996).

Most of these studies estimate single equation models that face two types of econometric problem:

- Simultaneity bias, where it is difficult to identify whether infrastructure stimulates economic performance, or whether infrastructure is provided as a response to demand in high growth regions; and

- Unobservable sources of heterogeneity, which make some regions more attractive (for investment) and influence local infrastructure supply or national infrastructure placement decisions.

Ignoring these issues makes identification questionable, and might exaggerate the contribution of public infrastructure to private investment or economic growth more generally.

In our application to Indian urban development, we address these problems by developing a structural model that examines how national infrastructure and local public services influence city performance. We build on several key contributions to the literature on infrastructure and economic growth (Rauch 1995; Morrison and Schwartz 1996; Fernald 1999; Röller and Waverman 2001), and also draw upon the role of market access in the new economic geography literature (Krugman 1991; Venables 1996; Head and Mayer 2004). One of the key papers in this literature is Röller and Waverman (2001). In their model of the telecommunication industry's contribution to economic growth, investments in the sector are endogenized through a model of supply and demand, which is jointly estimated with an aggregate production function. Our model extends this work in several dimensions.

First, we distinguish national infrastructure investment and placement decisions from city-level infrastructure supply decisions. By instrumenting national infrastructure placement and endogenizing local infrastructure service provision, we can assess what part of city success can be influenced by local efforts relative to national planning decisions and fixed natural endowments. Second, we add the public finance of local infrastructure service provision and endogenize this financing mechanism. This allows us to examine the relative effectiveness of various public financing schemes in increasing local infrastructure supply capacity.

Finally, we empirically address the reverse causality or simultaneity bias issue by providing time lags between manufacturing investment and the explanatory variables in 
a structural model. We chose a relatively long time lag of three years, such that local factors in year $t$ influence firm investments in $(t+3)$. In this way, we control for possible reverse causality coming from firm investment to local infrastructure response. We also test the robustness of empirical results by comparing various estimation methods (OLS, single equation GMM, and 3SLS), and introduce fixed effects that reflect state-level unobserved characteristics that could influence city performance as well as infrastructure provision.

\subsection{Model of infrastructure and city competitiveness}

We begin by assuming that investment, $I$, in the ith city responds to expected profits:

$$
I_{i}=f\left(M A_{i}, I N F_{i}, L I N_{i}, B S_{i}, X_{i}, \xi_{i}, \eta_{i}\right)
$$

In the specification in Equation (1), $M A_{i}$ represents agglomeration economies by means of regional market access attributes, which link city producers to intermediate inputs and domestic markets. $I N F_{i}$ captures the effects of national transport infrastructure linking cities to ports and trans-shipment hubs. These two factors depend on the endowment of interregional transport infrastructure, which, in the Indian context, is largely determined by national and state-level investment decisions. $\operatorname{LIN}_{i}$ represents local public infrastructure offered by the ith city. $B S_{i}$ are complementary business services provided by the private sector in city $i$. Other observable city attractors, such as local wage rates, are included in $X_{i}$.

Next, $\xi_{i}$ measures unobserved characteristics of the city that can affect returns to investment. These factors are considered by the investor when choosing a city to invest in, but are not captured in the data. These unobserved characteristics can complicate the identification of infrastructure's contribution if they influence the way in which (national) infrastructure is allocated across cities. As it is impossible to obtain data on all the factors relevant to infrastructure allocation decisions, it is essential to find instruments for infrastructure placement that are not correlated with the unobservable sources of city attraction or preference. Finally, $\eta_{i}$ is an idiosyncratic unobserved component of profitability in city $i$.

In our model, we endogenize local infrastructure provision through the interaction of (per capita) infrastructure supply $\left(g^{s}\right)$ and demand $\left(g^{D}\right)$ equations:

$$
\begin{aligned}
& \ln g^{D}=a_{0}-a_{1} \ln P+a_{2} \ln y+\Omega \\
& \ln g^{S}=b_{0}+b_{1} \ln P+b_{2} \ln (\text { cost })+b_{3}(\text { tax })+b_{4} \ln (\text { transfer })+\Omega \\
& g^{D}=\theta \cdot g^{S}
\end{aligned}
$$

where $a_{i}, b_{i} \geq 0$. Following Röller and Waverman (2001), we consider 'effective' demand rather than 'observed' demand for infrastructure services. The effective demand takes into account the un-met demand, which cannot be observed due to supply constraints. More formally, the un-met demand can be defined by the gap between normative infrastructure usage requirement and the actual infrastructure service 
provision. In our model, $\theta=\frac{g^{D}}{g^{S}}$ measures the size of un-met demand relative to the observed level of infrastructure service provision.

The price of infrastructure, $P$, can be defined by how much consumers pay for consuming one unit of infrastructure service (in the form of user charges and tariffs). Per capita infrastructure demand $\left(g^{D}\right)$ then depends on price $(P)$ and income $(y)$ elasticities. User charges or tariffs are revenue sources to the service providers, so the supply of infrastructure $\left(g^{s}\right)$ also responds to the price of infrastructure, the average cost of infrastructure service provision (cost), and the revenue income of local governments in the form of municipal tax receipts (tax) and transfers from higher levels of government (transfer). Very few public utilities in Indian cities will cover the full cost of service provision through direct user charges. The parameters $b_{3}$ and $b_{4}$ thus measure the effectiveness of different financing schemes. Infrastructure supply costs will also be determined by various local physical attributes, such as technological, topographical, or geographical factors. For instance, if there are insufficient reliable water sources close to a city, transporting water from far away will increase the cost of provision. Finally, various observed and unobserved local characteristics $(\Omega)$ influence the supply and demand of local infrastructure.

The two general revenue sources - local taxes, and transfers from higher levels of government - might themselves be endogenously determined by local, state, and national governments. Adding two structural equations that endogenize financing mechanisms, even though in a crude form, could correct potential simultaneity bias and provide an insight into local revenue dynamics. We therefore model these two financing mechanisms in a simple way, such that:

$$
\begin{aligned}
& \ln (\text { tax })=c_{o}+c_{1} \ln y+\Omega \\
& \ln (\text { transfer })=d_{o}+d_{1} \ln y+\Omega
\end{aligned}
$$

Tax revenues and transfers to local governments are assumed to be influenced by per capita local income levels $(y)$ and various local characteristics $(\Omega)$.

We construct systems of regression equations by combining the structural equations of Equations 1 to 5, and estimate the models individually and jointly.

\section{Data}

\subsection{Private investments}

For the empirical analysis, we have compiled city-level data from various sources and created indicators for various types of local and regional infrastructure. The city-level data on private sector manufacturing investment come from the CapEx database, maintained by the Centre for Monitoring Indian Economy (CMIE). By law, any private investment of more than 100,000 rupees must be registered with the Reserve Bank of India. CMIE keeps records of new and ongoing investment activities that are usually 
related to setting up new plants and machinery throughout the country. Investment projects are tracked from the time they are announced until their commissioning. While CMIE has been compiling information at the state level since 1995, we worked with CMIE officials to produce district- and city-level summaries of manufacturing investment by the private and public sectors. Such datasets for other countries often attribute specific investments to a company headquarters rather than to the branch location where the factory is located. Fortunately, the records of Indian private manufacturing investment identify investment by actual geographical location.

We use each city's share of national manufacturing investment in the empirical analysis. For each year, this indicator provides us with a snapshot of a city's economic competitiveness as it helps us examine how a city is doing relative to its peers. Table 1 shows the top 20 cities with the highest national shares of private manufacturing investment between 2000 and 2005. These 'superstar cities' (Gyourko et al. 2006) received about 60 per cent of all national manufacturing investment during the period.

Table 1: Top 20 cities with highest private manufacturing firm investment, 2000-05

\begin{tabular}{cllc}
\hline Ranking & State & UA/district & $\begin{array}{c}\text { National share of private } \\
\text { manufacturing firm investment, \% }\end{array}$ \\
\hline 1 & GUJARAT & Jamnagar UA & 6.267 \\
2 & PUNJAB & Rampura Phul UA & 5.194 \\
3 & MAHARASHTRA & Raigarh & 4.897 \\
4 & TAMIL NADU & Chennai UA & 4.693 \\
5 & ANDHRA PRADESH & Chittoor & 4.683 \\
6 & JHARKHAND & Jamshedpur UA & 3.115 \\
7 & ORISSA & Cuttack UA & 3.029 \\
8 & KARNATAKA & Bangalore UA & 2.907 \\
9 & KARNATAKA & Bellary & 2.729 \\
10 & UTTAR PRADESH & Sultanpur & 2.645 \\
11 & KERALA & Kanhangad UA & 2.617 \\
12 & MADHYA PRADESH & Sagar UA & 2.547 \\
13 & ASSAM & Dibrugarh UA & 2.351 \\
14 & ORISSA & Byasanagar UA & 2.150 \\
15 & MAHARASHTRA & Pune UA & 1.803 \\
16 & ORISSA & Ganjam & 1.777 \\
17 & CHHATTISGARH & Korba & 1.698 \\
18 & KARNATAKA & Mangalore UA & 1.610 \\
19 & GUJARAT & Bhuj UA & 1.570 \\
20 & UTTAR PRADESH & Modinagar UA & 1.465 \\
Total & & & 59.748 \\
\hline S0ure: & & \\
\hline
\end{tabular}

Source: CMIE, CapEx database. 
At the top of the list is the Jamnagar urban agglomeration in the state of Gujarat, which accounted for 6.3 per cent of national private manufacturing investment. Jamnagar is located on the Gulf of Kutch. It has a well functioning seaport and is near one of the world's largest refineries, run by the Reliance group of industries. Other cities listed in the top 20 include Raigarh (Maharashtra), which is adjacent to the Mumbai metro region; Pune (Maharashtra), which is $250 \mathrm{~km}$ from Mumbai; Chennai (formerly Madras); and Bangalore. Among the top 20 manufacturing investment cities, there are three in both Karnataka and Orissa, while the states of Gujarat, Maharashtra, and Uttar Pradesh each have two.

\subsection{Regional infrastructure}

To understand how public infrastructure influences city performance, we developed several measures of national transport infrastructure, and city-level public services and infrastructure (water supply and drainage, street lights, and municipal roads). Many studies on transport infrastructure and growth use state or local-level paved road length or road density as the measure of choice. For instance, in a recent paper on India, Hulten et al. (2006) use data on paved road length from the Ministry of Transport's Basic Road Statistics publication. The road data are disaggregated into national highways (arterial roads for interstate movement), state highways (arterial roads for inter-district movement, linking up with national highways and adjacent state highways), and district roads (other Public Works Department roads). The authors acknowledge that lack of data on road capacity (lanes) might be a problem, but a more general caveat is the sometimes arbitrary assignment of roads to categories that are only vaguely defined. For example, state governments routinely change the nomenclature of roads, and classify state highways as national highways and district highways as state highways. In most cases, these re-classifications are not accompanied by improvements in quality. As a consequence, figures on road networks maintained by the national government are misleading, since changes of classification cannot usually be distinguished from new road construction.

A further problem with road length or density indicators is that, in studies of economic performance, it is not the presence of roads or the total length of the local network that is important but, rather, whether the roads provide fast and convenient access to places of importance. In the present study, therefore, we utilize a geographically explicit measure of market access that is based on detailed spatial data of India's interregional transport network following the approach outlined in Lall et al. (2004). Using a Geographic Information System (GIS), we compute for each city the shortest route to other cities as of 1991, which represents potential input and output markets. Travel time is determined by distance and the design speed of each link in a quality differentiated road network. The summary indicator for each urban area in our analysis is the standard market access (or population potential) measure, which is defined as the sum of the population of target cities inversely weighted by the travel time required to reach them. No detailed interaction data are available that would allow us to estimate the distance decay function that models the decreasing influence of markets with increasing distance. We therefore follow standard convention by using a negative exponential function. The resulting market access indicator provides a generalized measure of regional infrastructure endowment. Additionally, we use a more direct indicator - the travel time to seaports on the interregional transport network - as a measure of distance from transshipment hubs. 


\subsection{Local infrastructure supply}

These data draw on the Local Finance Data System (LFDS) developed by the National Institute of Public Finance and Policy (NIPFP). This database has extensive information on local infrastructure service provision and fiscal conditions of local governments The final sample used in this analysis includes data for 151 Indian cities in 1992/93 and 1997/98. These cities represent 100 urban agglomerations (UA) (which often consist of several individual municipalities) and 51 non-UA cities. In our analysis, we use per capita figures on water supply released, drainage length, solid waste collection, surface municipal road length, and streetlights. Better local infrastructure will have a direct benefit on local production, but also reflects the quality of urban management more generally. Rather than using all variables as predictors, we produce a summary measure of local infrastructure supply as the first principal component of the log values of the five individual indicators. ${ }^{1}$

We calculate per capita normative expenditure level following the guidelines initially developed by the Zakaria Committee (Zakaria 1963). This committee developed per capita expenditure requirements for adequate public services based on physical norms and standards. These norms were stratified for five size categories of towns and covered water supply, drainage and sewerage, roads and works, and streetlights and electricity distribution. Since the initial norms are somewhat out of date, we instead use reconstructed and updated estimates by Mathur (2001) at 1998-99 prices. We compute a corresponding summary of municipal infrastructure expenditure from the LFDS that encompasses the same public services.

The local infrastructure price in the demand equation (Equation 2), $P$, can be measured by how much local residents pay for the consumption of each local infrastructure service in the form of tariffs and user charges. We assume local governments' (per capita) receipts of user charges/tariffs are equal to (per capita) non-tax revenue receipts, or proportional to them. Specifically, the price of local infrastructure is proxied, such that:

$$
\begin{aligned}
\ln P & =\ln \left(P \cdot g^{S}\right)-\ln g^{S}=\ln \left(\begin{array}{c}
\text { per capita } \\
\text { infra purchase }
\end{array}\right)-\ln g^{S} \\
& =\ln \left(\frac{\text { non tax revenue receipts / city population }}{\text { CPI/100 }}\right)-\ln g^{S},
\end{aligned}
$$

where CPI is the all India consumer price index (CPI) for urban non-manual employees with $1984-85$ as the base year.

The average (per capita) cost of local infrastructure service provision, deflated by the CPI, is defined as:

$$
\ln a c=\ln \left(\frac{\text { municipal infrastructure expenditure / city population }}{\text { CPI / } 100}\right)-\ln g^{s} \text {. }
$$

1 This indicator preserves 33 per cent of the variance in the original set of variables. 
In addition to direct user charges, local government expenditures on public services are also financed by local taxes or transfers from higher levels of government. We construct these variables such that $\ln \operatorname{tax}=\ln$ (municipal tax receipts, per capita, real), and ln transfer $=\ln$ (total transfers from higher levels of governments, per capita, real), both of which are deflated by the CPI.

Average per capita city income, ln $y$, is proxied by the first principal component of:

(i) $\ln ($ per capita net state domestic product at factor cost, at constant price);

(ii) $\ln ($ municipal total tax revenue receipts, per capita, real); and

(iii) $\ln ($ per capita waste generated).

Table 2 summarizes the main variables used in the analysis.

Table 2: Summary statistics

\begin{tabular}{lrrrrr}
\hline Variable & Obs & Mean & Std dev. & Min. & Max. \\
\hline Local infra supply & 302 & 2.079 & 2.964 & 0.009 & 25.700 \\
Avg. distance to ports, hours & 244 & 13.112 & 12.724 & 0.010 & 46.354 \\
Market access & 254 & 12165 & 11164 & 216 & 66976 \\
Wages, per worker, real (Rs) & 200 & 5819 & 2470 & 1073 & 13005 \\
Net value-added, per employee, real (Rs) & 209 & 64281 & 122640 & 3477 & 1264801 \\
Business service jobs, per capita & 284 & 0.155 & 0.399 & 0.000 & 3.656 \\
Local infra demand & 302 & 8.603 & 15.562 & 0.056 & 185.247 \\
Local infra price & 302 & 0.042 & 0.105 & 0.000 & 0.883 \\
Local avg. income & 296 & 2.658 & 3.649 & 0.025 & 29.762 \\
Avg. cost of local infra supply & 302 & 0.076 & 0.203 & 0.001 & 2.361 \\
Local tax revenue, per capita (1000 Rs) & 302 & 0.062 & 0.088 & 0.000 & 0.656 \\
Transfers, per capita (1000 Rs) & 300 & 0.046 & 0.038 & 0.002 & 0.382 \\
\hline
\end{tabular}

\section{$4 \quad$ Main findings}

In this section, we report results from specifications estimating the contribution of infrastructure to city-level competitiveness. We discuss results from the model estimated with three-stage least squares estimators (3SLS). We also estimated specifications with ordinary least squares (OLS) and generalized method of moments (GMM) estimators - these are available on request.

In Table 3, we combine the firm investment model with a model of the local infrastructure model of supply, demand, and financing. We construct a system of 
equations and estimate parameters using 3SLS. The system of equations consists of five components:

(i) Firm investment equation for private manufacturing;

(ii) A local wage rate equation;

(iii) Local infrastructure supply and demand equations;

(iv) Two local infrastructure financing equations of municipal taxes; and

(v) Transfers from higher levels of government.

The 3SLS estimators are preferred, as there is a major problem with identifying the effects of infrastructure using OLS. Estimates of market access and proximity to ports will probably be biased. As cities with good market access - and those close to international ports tend to be large cities - one would expect that these estimates might reflect unobserved benefits from agglomeration economies. At the same time, historical regulations on urban land acquisition for industrial use in India, coupled with environment regulations that have made it difficult for manufacturing to locate in large cities, are likely to reduce the extent to which manufacturing can locate in medium- to large-scale agglomerations. Our measures of national infrastructure development are correlated with unobserved sources of heterogeneity at the city level. We address this problem using instrumental variables.

The instruments include a dummy variable for port cities (distances to ports by roads or rail are less than five hours), a dummy for state capitals, and various state-level characteristics in the year 1970. The 1970 state characteristics are: population size; population density; per capita total state government revenue; the share of the manufacturing sector in the total Net State Domestic Product (NSDP); per capita NSDP; the share of the number of seats won by the Congress Party, hard-left parties, and softleft parties; a dummy for the president's (state) rule; a year dummy; and state dummies. ${ }^{2}$

The accumulation of infrastructure investments in the past will determine current physical infrastructure status. Time-invariant natural features, and economic and political conditions in the past, would have influenced infrastructure investments in the past and therefore be correlated with current infrastructure stocks. However, these natural and historical variables, by themselves, are not directly correlated with a manufacturing firm's investment decisions. For example, located in a state capital city or a state of high NSDP in 1970 does not 'directly' affect a manufacturing firm's future profit and its investment decision.

In Table 3, column 1 reports the investment equation for private manufacturing. We find that regional and national road transport improvements raise the attractiveness of a city for new investment. The parameter estimates suggest that a 10 per cent reduction in travel time to international ports increases a city's share of national private manufacturing investment by 5.3 per cent. ${ }^{3}$ Similarly, a 10 per cent increase in the measure of road transport links that enhance domestic market access increases a city's

2 These state-level data come from the EOPP (Economic Organization and Public Policy Programme) Indian State Database at London School of Economics.

3 City's national investment share variable is multiplied by 1000 . 
Table 3: Manufacturing firm investment and local infrastructure:

3SLS (standard errors in parentheses)
(2)
(3)

(1)

(4)

(5)

(6)

\begin{tabular}{|c|c|c|c|c|c|c|}
\hline $\begin{array}{l}\text { Dependent } \\
\text { variable }\end{array}$ & 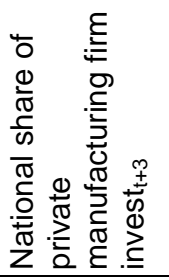 & 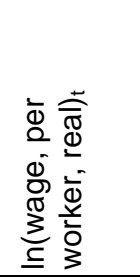 & 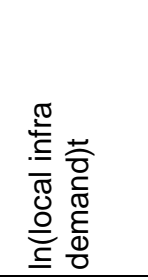 & 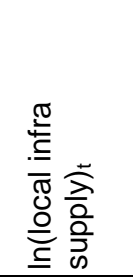 & 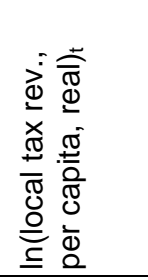 & 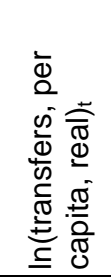 \\
\hline & $3 S L S$ & $3 S L S$ & $3 S L S$ & $3 S L S$ & $3 S L S$ & $3 S L S$ \\
\hline In(local infra $)_{t}$ & $\begin{array}{l}1.179^{\star \star} \\
(0.590)\end{array}$ & $\begin{array}{l}-0.150^{\star \star} \\
(0.073)\end{array}$ & & & & \\
\hline $\begin{array}{l}\text { In(avg. distance } \\
\text { to ports, hrs) }\end{array}$ & $\begin{array}{l}-5.379^{\star \star \star} \\
(1.848)\end{array}$ & $\begin{array}{l}-0.031 \\
(0.190)\end{array}$ & & & & \\
\hline $\begin{array}{l}\text { In(market } \\
\text { access) }{ }_{1991}\end{array}$ & $\begin{array}{l}5.873^{\star \star \star *} \\
(2.216)\end{array}$ & $\begin{array}{l}-0.061 \\
(0.252)\end{array}$ & & & & \\
\hline $\begin{array}{l}\text { In(wage, per } \\
\text { worker, real)t }\end{array}$ & $\begin{array}{l}-5.769^{\star *} \\
(2.285)\end{array}$ & & & & & \\
\hline $\begin{array}{l}\text { In(bus. serv. job, } \\
\text { per capita) } 2001 \\
\text { In(net value-add, } \\
\text { per emp., real)t }\end{array}$ & $\begin{array}{l}-0.783 \\
(0.583)\end{array}$ & $\begin{array}{l}0.029 \\
(0.069) \\
0.897^{\star \star \star} \\
(0.220)\end{array}$ & & & & \\
\hline $\begin{array}{l}\text { In(local avg. } \\
\text { Income)t }\end{array}$ & & & $\begin{array}{c}1.561 \\
(1.185)\end{array}$ & & $\begin{array}{l}2.167^{\star \star \star} \\
(0.172)\end{array}$ & $\begin{array}{c}0.445 \\
(0.297)\end{array}$ \\
\hline In(local infra & & & $-1.376^{\star \star \star}$ & 0.109 & & \\
\hline price) $)_{t}$ & & & $(0.188)$ & (0.954) & & \\
\hline $\ln (\operatorname{avg} \cdot \operatorname{cost})_{t}$ & & & & $\begin{array}{l}-1.023 \\
(0.737)\end{array}$ & & \\
\hline $\begin{array}{l}\text { In(local tax rev., } \\
\text { per capita, real)t }\end{array}$ & & & & $\begin{array}{l}0.683^{*} \\
(0.399)\end{array}$ & & \\
\hline $\begin{array}{l}\text { In(transfers, } \\
\text { per capita, real)t }\end{array}$ & & & & $\begin{array}{c}0.332 \\
(0.596)\end{array}$ & & \\
\hline A year dummy & Yes & Yes & Yes & Yes & Yes & Yes \\
\hline State dummies & Yes & Yes & Yes & Yes & Yes & Yes \\
\hline Constant & Yes & Yes & Yes & Yes & Yes & Yes \\
\hline Observations & 155 & 155 & 155 & 155 & 155 & 155 \\
\hline RMSE & 5.705 & 0.639 & 1.219 & 0.706 & 0.344 & 0.596 \\
\hline
\end{tabular}

Notes: ${ }^{* \star}$ significant at $1 \%$ level; ${ }^{* *}$ significant at $5 \%$ level; * significant at $10 \%$ level.

The instruments are:

(i) The average (real) cost of local infrastructure service provision, In(avg. cost), which is assumed to be exogenously determined by technological and topographical/geographical factors;

(ii) A dummy for port cities (distances to ports by roads or rails are less than 5 hours);

(iii) A dummy for state capitals;

(iv) A year dummy and state dummies; and

(v) Various state characteristics in year 1970. The 1970 state characteristics include population size; population density; per capita total state government revenue; the share of manufacturing sector in the total NSDP; per capita NSDP; the share of the number of seats won by Congress Party, hard left parties, and soft left parties; a dummy for president's (state) rule. 
share of national private manufacturing investment by 5.8 per cent. The index of local infrastructure also has positive and significant effect on city investment; improving the local public infrastructure index by 10 per cent increases a city's private manufacturing share by 1.2 per cent.

In summary:

(i) Access to national infrastructure has significant effects on private manufacturing investment decisions;

(ii) Local infrastructure has a positive and significant effect; and

(iii) Local economic conditions, such as prevailing local wage rates, influence location decisions.

We find that manufacturing investment is negatively influenced by local wages, and a 10 per cent increase in the wage rate reduces investment shares by 5.7 per cent. Quite surprisingly, access to business services does not have a significant effect on private investment decisions after controlling for physical infrastructure.

The estimation results of the local (real) wage rate equation are in column 2 . We first control for the net value-added per employee as a measure of labour productivity, which is statistically significant and positive, as expected. With regard to local factors in local wage determination, we observe interesting results. First, better local infrastructure service provision does, indeed, decrease the local wage rate. This finding is consistent with the cost of living compensation effect of Haughwout (2002). He proposes that, as local income levels and local amenities determine the welfare of local residents, firms can pay lower wages to local workers in the cities that provide better infrastructure services. Second, better access to national transport infrastructure does not have additional effects on local wage determination, as it is already incorporated into local labour productivity (net value-added per employee).

Columns 3 to 6 are the 3SLS estimates of Equations (2) and (3) for infrastructure supply and demand. We also add state dummies and a year dummy to control for unobserved attributes.

The coefficient estimate of the price elasticity of local infrastructure demand is statistically significant, with an expected negative sign. The price elasticity of local infrastructure supply has the expected positive sign, but is not statistically significant. This might imply that local governments provide infrastructure services on a nonmarket pricing basis, emphasizing the role of governments as public good providers. Local infrastructure provision costs have a negative effect on supply, as expected.

Interestingly, municipal tax receipts (per capita, real) have a statistically significant and positive effect on local infrastructure supply, but the effect of transfers from higher levels of government is not significant. Thus, improving municipal revenue sources is a more effective way to finance and improve the supply of city-level infrastructure services. Other variables - such as the income elasticity of local infrastructure demand, and the cost of infrastructure supply - are less significant (significant at the 20 per cent level) but retain expected signs. 


\section{Conclusion}

In this paper, we assessed the impact on city competitiveness of infrastructure provision by explicitly modelling infrastructure supply, demand, and finance. For the analysis, we distinguished between national infrastructure investment and placement decisions from city-level infrastructure supply decisions in order to identify what part of a city's success can be influenced by local efforts, relative to national planning decisions and fixed natural endowments.

To identify the impacts of infrastructure endowments, we revisited the debate on infrastructure and economic performance, which came into empirical prominence in the early 1990s. Most papers contributing to that debate faced identification problems arising from omitted variables and reverse causality. We address these issues by developing a structural model in which local infrastructure supply and demand are endogenously determined, and the effects of interregional infrastructure are separated from unobserved city-level sources of heterogeneity. We collect a new dataset on private manufacturing investment by city, and take each city's share of national investment over time to reflect its competitiveness.

Our results highlight three important issues. First, we find that access to interregional infrastructure, measured by domestic market access and travel time to seaports, has considerable and significant effects in improving a city's attractiveness for private investment. Our indicator of market access is based on the new economic geography literature, and improves on commonly used road length or density variables as these are fraught with measurement error and do not account for network connectivity. Second, the supply of local infrastructure services has a positive and significant effect on citylevel attractiveness to investment. Our measures of local infrastructure include municipal roads, street lighting, water supply, and drainage. These effects are robust across econometric specifications and estimation procedures. The effect of market access and proximity to ports is much greater than the effects of local infrastructure supply, indicating that a large part of city success is influenced by national programme placement decisions and a city's natural geography. Local efforts are important, but are not the main determinants of city competitiveness.

Third, local infrastructure supply is most sensitive to a city's ability to raise its own revenues by means of local taxes and user fees. While simple correlations show that both local revenues and transfers are associated with infrastructure supply, causality can only be established for own-source revenues.

In India, as in many other countries, city mayors and managers are keen to improve economic competitiveness. The zeal for economic success is seen across cities - large and small, well connected and poorly connected. And city leaders lobby state and federal governments to increase their share of public investment. The analysis in this paper shows that investments in locally provided infrastructure services improve quality of life for residents but may not translate into economic success for cities far from large domestic markets and major sea ports. And compared to transfers from higher levels of government, expenditures from a city's own revenues are better reflected in service improvements

The policy implication for improving local service delivery is to find mechanisms that would expand local revenue bases in economically depressed cities. However, this is not 
an easy task as local tax bases in these places are not buoyant and local governments do not have the autonomy to change local tax rates or the administrative capacity to improve collection efficiency.

In the short run, there may be need to increase the scale of transfers that are dedicated for service delivery (as in ring fenced operations). This is likely to stimulate benefits in terms of improvements in household welfare and willingness to pay for services via direct user charges (as households see visible improvements in service performance). In the medium to long run, efforts should be placed at improving local revenue capacity using a combination of new valuation methods and enhanced administrative capacity. If an area-based system is adopted, as is used now in some of the larger cities in the country, then a method of updating the guidance values on a regular basis is necessary (see Lall and Deichmann 2006 for details). This will require not only reliable values from the Stamp Office, and from the state Ministries of Construction, but also a set of procedures for updating these values. It also will require trained staff, capable of valuing real property, and perhaps a central valuation unit in each state should be considered.

There is much to be done to implement such a system. Most local governments do not have a cadre of trained assessors to evaluate property values and update them regularly. A capital value system is even more difficult, because valuation of individual units will be required. In either case, a method of requiring updating of any new construction or major renovations, subdivisions, etc. will need to be put in place. A capital value system will be difficult and costly to implement, and it will be expensive. Its introduction will require much careful planning and will take considerable time.

\section{References}

Ahluwalia, M. (2002). 'Economic Reforms in India since 1991: Has Gradualism Worked?'. Journal of Economic Perspectives, 16: 67-88.

Aschauer, D. (1989). 'Is Public Expenditure Productive'. Journal of Monetary Economics, 23: 177-200.

Bajpai, N., and Sachs, J. (1999). 'The Progress of Policy Reform and Variations in Performance at the Sub-National Level in India'. HIID Development Discussion Paper 730. Cambridge, MA: Harvard Institute for International Development.

CMIE (Centre for Monitoring Indian Economy). CapEx database. Mumbai: CMIE. Available at: www.cmie.com/database/?service=database-products/firm-level-dataservices/capex-investment-project.htm

Fernald, J. (1999). 'Roads to Prosperity? Assessing the Link between Public Capital and Productivity’. American Economic Review, 89: 619-38.

Garcia-Mila, T., and McGuire, T. (1996). 'The Effect of Public Capital in State-Level Production Functions Reconsidered'. Review of Economics and Statistics, 78(1): 177-80.

Gyourko J., Mayer, C., and Sinai, T. (2006). 'Superstar Cities'. NBER Working Paper 12355. Cambridge, MA: National Bureau of Economic Research. 
Haughwout, A. (2002). 'Public Infrastructure Investments, Productivity and Welfare in Fixed Geographic Areas’. Journal of Public Economics, 83: 405-28.

Head, K., and Mayer, T. (2004). 'Market Potential and the Location of Japanese Firms in the European Union'. Review of Economics and Statistics, 86: 959-72.

Hirschman, A. (1958). The Strategy of Economic Development. New Haven: Yale University Press.

Holtz-Eakin, D., and Schwartz, A. (1995). 'Infrastructure in a Structural Model of Economic Growth’. Regional Science and Urban Economics, 25: 131-51.

Hulten, C., Bennathan, E., and Srinivasan, S. (2006). 'Infrastructure, Externalities, and Economic Development: A Study of the Indian Manufacturing Industry'. World Bank Economic Review, 20(2): 291-308.

Krugman, P. (1991). 'Increasing Returns and Economic Geography'. Journal of Political Economy, 99: 483-99.

Lall, S.V., Shalizi, Z., and Deichmann, U. (2004). 'Agglomeration Economies and Productivity in Indian Industry'. Journal of Development Economics, 73(2): 643-73.

Lall, S.V. and U. Deichmann (2006). "Fiscal and Distributional Implications of Property Tax Reforms in Indian Cities’. Economic and Political Weekly, July 22: 3209-3220.

Mathur, O.P. (2001). Approach to State-Municipal Fiscal Relations: Options and Perspectives. New Delhi: National Institute of Public Finance and Policy.

Moomaw, R., Mullen, J., and Williams, M. (1995). 'The Interregional Impact of Infrastructure Capital'. Southern Economic Journal, 61: 830-45.

Morrison, C., and Schwartz, A. (1996). 'State Infrastructure and Productive Performance'. American Economic Review, 86: 1095-111.

Munnell, A. (1990). 'How Does Public Infrastructure Affect Regional Economic Performance'. New England Economic Review, 30: 11-32.

Nadiri, I. (1970). 'Some Approaches to the Theory and Measurement of Total Factor Productivity: A Survey’. Journal of Economic Literature, 8: 1137-77.

Nurkse, R. (1953). Problems of Capital Formation in Underdeveloped Countries. Oxford: Basil Blackwell.

Rauch, J. (1995). 'Bureaucracy, Infrastructure, and Economic Growth: Evidence from US Cities during the Progressive Era'. American Economic Review, 85: 968-79.

Röller, L.-H., and Waverman, L. (2001). 'Telecommunications Infrastructure and Economic Development: A Simultaneous Approach'. American Economic Review, 91: 909-23.

Venables, A. (1996). 'Equilibrium Locations of vertically Linked Industries'. International Economic Review, 37: 341-59.

Zakaria, R. (1963). 'Report of the Committee of Ministers constituted by the Central Council of Local Self Government on Augmentation of Financial Resources for Urban Local Bodies'. New Delhi: Government of India. 